\title{
Социология
}

\begin{abstract}
РЫБАКОВСКИЙ Леонид Леонидович - доктор экономических наук, профессор; главный научный сотрудник Института демографических исследований Федерального научно-исследовательского социологического центра РАН (119333, Россия, г. Москва, ул. Фотиевой, 6, корп. 1)

КУЗИНА Светлана Ивановна - доктор политических наук, профессор кафедры политологии и этнополитики Южно-Российского института управления - филиала Российской академии народного хозяйства и государственной службы при Президенте РФ (344002, Россия, г. Ростов-на-Дону, ул. Пушкинская, 70/54)

ПОНЕДЕЛКОВ Александр Васильевич - доктор политических наук, профессор; заведующий лабораторией проблем повышения эффективности государственного и муниципального управления, заведующий кафедрой политологии и этнополитики Южно-Российского института управления - филиала Российской академии народного хозяйства и государственной службы при Президенте РФ (344002, Россия, г. Ростов-на-Дону, ул. Пушкинская, 70/54; ponedelkov@uriu.ranepa.ru); заслуженный деятель науки РФ
\end{abstract}

\section{ЭКСПЕРТНОЕ СООБЩЕСТВО О ДЕМОГРАФИЧЕСКОЙ СИТУАЦИИ В СОВРЕМЕННОЙ РОССИИ}

\begin{abstract}
Аннотация. В статье рассматривается демографическая ситуация в современной России. Анализ результатов экспертного опроса, проведенного в регионах России, позволил определить основные причины депопуляции и наметить направления государственной политики по преодолению демографического кризиса.
\end{abstract}

Ключевые слова: демографический кризис, естественный прирост, депопуляция, население, государственная политика, регионы России, демографическое развитие 26 апреля 2021 г. в г. Ростове-на-Дону на базе Южно-Российского института службы при Президенте РФ (далее - ЮРИУ РАНХиГС) в дистанционном формате состоялась Всероссийская научно-практическая конференция с международным участием «Демографическое развитие России: проблемы и пути решения». Организатором конференции выступила лаборатория проблем повышения эффективности государственного и муниципального управления ЮРИУ РАНХиГС. В конференции вместе с учеными ЮРИУ РАНХиГС приняли участие представители Института демографических исследований Федерального научно-исследовательского социологического центра Российской академии наук (ФНИСЦ РАН) (г. Москва); Московского государственного университета имени М.В. Ломоносова (г. Москва); Общественной палаты Ростовской области; Российского общества политологов; Ленинградского государственного университета имени А.С. Пушкина (г. Санкт-Петербург); Ассоциации «Совет муниципальных образований Ростовской области»; Министерства социальной защиты Алтайского края (г. Барнаул); Башкирского института социальных технологий (филиала) Академии труда и социальных отношений (г. Уфа); Карачаево-Черкесского государственного университета имени У.Д. Алиева (г. Карачаевск); Таганрогского института имени А.П. Чехова (филиала) Ростовского государственного экономического университета (РИНХ); Ростовского филиала Московского государственного технического университета гражданской авиации (г. Ростов-на-Дону); филиалов РАНХиГС и др.

С приветственным словом от имени директора Южно-Российского института управления-филиала РАНХиГС В.В. Рудого выступил заместитель 
директора $\boldsymbol{A . B . ~ Б а р а н о в , ~ к о т о р ы и ̆ ~ и ~ о т к р ы л ~ к о н ф е р е н ц и ю , ~ п о ж е л а л ~ у с п е ш н о и ̆ ~}$ работы, обозначив основные направления работы форума и актуальность его тематики, отметив, что демографические характеристики являются фундаментальными параметрами любого государства. Демография необходима для разработки стратегии экономического развития государства, его социальной политики. Эти обстоятельства обусловливают устойчивый научный и общественный интерес к проблеме народонаселения, к различным ее аспектам.

С пленарным докладом выступил член-корреспондент РАН, доктор экономических наук, профессор, директор Института демографических исследований ФНИСЦ РАН $\boldsymbol{C . B .}$ Рязанщев. В нем он проанализировал демографические последствия пандемии COVID-19, проинформировал участников конференции о направлениях демографической политики правительства России в сегодняшней сложной обстановке.

Доктор экономических наук, профессор, главный научный сотрудник Института демографических исследований ФНИСЦ РАН Л.Л. Рыбаковский в своем выступлении раскрыл стратегию демографического развития России, ее основной вектор и его детерминанты. Проанализировав динамику численности населения России в течение ее истории, ученый акцентировал свое внимание на демографической ситуации в последние десятилетия и сделал соответствующие выводы: в настоящее время в России реализуются национальные проекты по улучшению ситуации в различных сферах жизнедеятельности общества, принимаются меры по оздоровлению демографического развития страны. Чтобы придать этим мерам целенаправленный характер, они должны быть дополнены таким юридически оформленным документом, как Стратегия демографического развития России.

В своем выступлении заслуженный деятель науки РФ, доктор политических наук, профессор, заведующий лабораторией проблем повышения эффективности государственного и муниципального управления ЮРИУ РАНХиГС, заведующий кафедрой политологии и этнополитики, член Общественной палаты Ростовской области $\boldsymbol{A}$.B. Понеделков рассмотрел демографическое будущее России в геополитических и социально-экономических координатах. В 19501960-х гг. мировая демографическая политика была ориентирована на решение назревающей глобальной проблемы демографического взрыва - перенаселения планеты. В этот период население Азии, Африки и Латинской Америки быстро росло - от $2 \%$ до $4 \%$ в год. Страх перед демографическим взрывом обострил внимание к проблемам ресурсного обеспечения будущего населения и его расселения. С 1970-х гг. в центре внимания мировой демографической политики оказалась проблема резкого падения рождаемости в экономически развитых странах. В настоящее время в более чем 60 странах мира рождаемость не обеспечивает даже простого воспроизводства населения. В этих странах проживают около половины населения земного шара. В 20 странах уровень рождаемости уже более 20 лет значительно ниже уровня простого воспроизводства.

Заслуженный деятель науки РФ, доктор социологических наук, профессор, заместитель декана, заведующий кафедрой общественных связей и медиаполитики факультета журналистики Института государственной службы и управления РАНХиГС Ф.И. Шарков в своем докладе обратил внимание на то, что в большинстве стран приоритетным направлением демографической политики является регулирование рождаемости и сохранение семьи как социального института. В большинстве стран с резким ростом рождаемости в последние годы проводится политика контроля рождаемости. Как правило, в азиатских странах, которым угрожает демографический взрыв, демографическая политика ориентирована на снижение рождаемости. В странах Западной Европы, 
которым угрожает демографический кризис, демографическая политика ориентирована на повышение рождаемости.

В Целях устойчивого развития..., которые были приняты ООН, значится такой контрольный показатель, как суммарный коэффициент рождаемости. И довольно симптоматично, что документ есть на сайте Росстата, но в нем... не указано его значение. То есть, сама идеология «устойчивого развития» ООН в части демографической политики не может быть безусловным ориентиром для России. А идеология эта была разработана в недрах Римского клуба в 1970-х гг. и позже навязана в качестве глобального дискурса. Ее изначальной целью было сдерживание роста численности населения планеты, а в перспективе - и его сокращение за счет снижения рождаемости. Историк Андрей Фурсов называет это идеологией «бархатного геноцида».

В конференции участвовали не только ученые, но и практические работники, представители органов муниципальной власти, которые поделились опытом реализации демографической политики в регионах. Так, заместитель министра труда и социального развития Ростовской области A.A. Харахашян проинформировал присутствующих об основных аспектах и передовых практиках, реализуемых в рамках национального проекта «Демография» в Донском крае. Министр социальной защиты Алтайского края H.B. Оськина рассказала о задачах, стоящих перед правительством края, включающих ориентацию на увеличение рождаемости при одновременном снижении уровня смертности, увеличение продолжительности жизни людей и достижение миграционного прироста. Заместитель министра по физической культуре и спорту Ростовской области $\boldsymbol{C}$.A. Гадарова отметила, что национальный проект «Демография» предусматривает увеличение доли жителей области, систематически занимающихся физической культурой и спортом, к 2030 г. до 70\%. Для успешной реализации данной задачи приняты Стратегия развития физической культуры и спорта в Ростовской области до 2030 года, региональный проект «Спорт - норма жизни», который предполагает развитие трех направлений: развитие массового спорта, подготовка спортивного резерва, развитие спортивной инфраструктуры.

Председатель городской думы - глава города Таганрога, доктор философских наук, профессор Института управления в экономических, экологических и социальных системах Южного федерального университета И.Н. Титаренко обратил внимание на отток населения в крупные города, центры агломераций (на основе данных о численности населения городских округов Ростовской области). Так, например, в Таганроге Ростовской области, по данным Росстата, на 01.01.2010 г. население составляло 255,1 тыс. чел., а на 01.01.2020 г. - уже 248,6 тыс. чел. Ученый уверен, что для предотвращения оттока населения из малых и средних городов, спасения от катастрофического снижения численности населения села, сохранения российской провинции нашим бесспорным, безусловным, императивным приоритетом демографического и пространственного развития должен стать декларируемый в Стратегии пространственного развития Российской Федерации до 2025 года дифференцированный подход к направлениям и мерам государственной поддержки социально-экономического развития территорий с учетом демографической ситуации, особенностей системы расселения, уровня и динамики развития экономики и специфических природных условий.

Роль муниципальных органов власти в реализации демографической политики сбережения российского народа отметил исполнительный директор Ассоциации совета муниципальных образований Ростовской области (г. Ростов-на-Дону) В.П. Ляхов. На сегодняшний день органы местного самоуправления решают демографическую проблему на местах с помощью муни- 
ципальных программ и комплексных планов, направленных на поддержку семьи, материнства и детства, на предупреждение семейного неблагополучия; повышения эффективности оказания первичной медико-социальной и реабилитационной помощи; развития и обеспечения доступности системы образования; проведения образовательных, культурно-массовых и информационных мероприятий, направленных на формирование в обществе семейных и нравственных ценностей, здорового образа жизни; формирования инвестиционной привлекательности и модернизации существующих предприятий; развития туристической привлекательности и сохранения исторической идентичности. Если обобщить, то можно сказать, что все направления деятельности муниципалитета напрямую или косвенно влияют на демографическую политику.

Значение обеспеченности населения жильем для положительного прироста населения в сельской местности рассмотрела и проанализировала глава Целинского сельского поселения Ростовской области О.К. Косенко. По данным мониторинга, молодые семьи, проживающие в районном центре, в 2,5 раза чаще, чем молодые семьи, проживающие в отдаленных хуторах и селах, планируют появление второго ребенка, и в 4,7 раза - появление третьего ребенка. Сейчас людям нужны в непосредственной близости не только, условно говоря, магазин, детский сад и аптека, но и спортивно-оздоровительный комплекс, парк с фонтаном и аттракционами, детская школа искусств.

На конференции выступили с докладами представители научных печатных изданий, осветив демографическую ситуацию со своей точки зрения, исходя из региональных реалий. Так, доктор социологических наук, профессор, главный редактор всероссийского научного журнала «Гуманитарные, социально-экономические и общественные науки» (г. Краснодар) М.Ю. Попов осветил региональные аспекты, влияющие на демографическую ситуацию в Краснодарском крае. Анализируя результаты опроса 100 экспертов из Краснодарского края, ученый делает вывод, что подавляющее большинство участников экспертного опроса практически единодушно охарактеризовали ее как тревожную и нуждающуюся в комплексном подходе к изменению демографической ситуации в стране в направлении повышения рождаемости, увеличения продолжительности жизни и сокращения смертности населения, чему должны способствовать:

- улучшение социально-экономической ситуации в стране, способствующей повышению доходов населения и качества его жизни;

- обеспечение со стороны государства эффективной внутренней и внешней политики, направленной на сохранение его целостности, экономической, политической и социальной безопасности;

- дальнейшее развитие государственных программ, направленных на материальную и социальную поддержку молодых семей;

- пропаганда ценностей традиционной семьи и государственно-правовая защита населения, и в первую очередь молодежи, от деформирующих ее сознание так называемой западной либеральной демократии и толерантности;

- обеспечение постоянного государственного контроля за реализацией государственных программ, направленных на стимулирование демографического развития России.

О демографическом развитии в других регионах России, таких как Арктическая зона, рассказал присутствующим доктор философских наук, профессор РАНХиГС (г. Москва) А.Н. Аверин. Он отметил, что Арктическая зона является стратегическим резервом развития минерально-сырьевой базы страны. Население сухопутных территорий Арктической зоны сокращается. В нормативных правовых документах отмечается, что сокращение численности населения является основной угрозой национальной безопасности в Арктике. 
Взаимовлияние рынка труда и демографической ситуации в Республике Башкортостан проанализировала доктор политических наук, доцент, директор Башкирского института социальных технологий (филиала) Академии труда и социальных отношений, заведующий кафедрой политологии, истории, теории государства и права T.A. Нигматуллина. От демографической структуры населения в значительной степени зависят параметры рынка труда, соотношение фондов накопления и потребления, размещение и развитие производительных сил, структура занятости и т.д.

Доктор политических наук, профессор кафедры международных отношений Кыргизско-Российского славянского университета им. Б.Н. Ельцина (Кыргизская Республика, г. Бишкек) Л.Л. Хоперская рассказала о демографии и миграции как факторах политических процессов в Киргизии. В 2018 г. численность рабочей силы в Кыргизской Республике составляла 2 538,7 тыс. чел., занятое население - 2 382,5 тыс. чел., уровень занятости 56,2\%. Именно эти группы молодого мужского трудоизбыточного населения, недовольные порядками и политическими институтами, неспособными обеспечить занятость и достойный уровень жизни, становятся социальной базой силовых захватов власти, осуществленных в Киргизии в 2005, 2010 и 2020 гг., интерпретируемых большинством экспертов как «цветные революции». Дальнейшие перспективы политической стабильности связаны с тем, что ежегодно на рынке труда Киргизии появляется примерно 50 тыс. новых участников.

Активное участие в конференции приняли ученые ЮРИУ РАНХиГС. Доктор экономических наук, профессор, декан факультета политологии T.П. Черкасова отметила взаимосвязь демографической ситуации в стране и уровня развития ее экономики. Доктор геолого-минераловедческих наук, профессор $\boldsymbol{A} . \boldsymbol{B}$. Кокин обратился к свойству золотого сечения (пропорции) при анализе динамики состояния демографической ситуации в прошлом, настоящем и будущем. Оказалось, что естественная природа изменения состояний и явлений не всегда (а чаще - никогда) не подчиняется статистике. Статистика нужна исследователям для того, чтобы оценить хотя бы вероятность событий, включенных в ту или иную выборку. Структуру этнического состава российского общества, трансформирующуюся под воздействием внутренних и внешних миграционных процессов, рассмотрела доктор политических наук, профессор С.И. Кузина. Миграция в многонациональной и поликультурной РФ выводит проблему внутренней и внешней безопасности на совершенно другой уровень, где основным фактором прогрессивного и устойчивого развития является этнокультурная и этнодемографическая стабильность. Доктор социологических наук, профессор, заведующий кафедрой социологии $\boldsymbol{P}$.K. Овчаренко проанализировал демографическую ситуацию в Республике Крым.

В конференции приняли участие и другие ученые из разных регионов России и зарубежья, а также молодые ученые ЮРИУ РАНХиГС - аспиранты, магистранты, студенты разных факультетов института.

Ученые-исследователи ЮРИУ РАНХиГС при подготовке к всероссийской научно-практической конференции с международным участием «Демографическое развитие России: проблемы и пути решения» провели в феврале-марте 2021 г. экспертный опрос в 23 субъектах РФ, в котором участвовали более 1400 экспертов из семи целевых групп, представлявших органы государственной и муниципальной власти, научное и образовательное сообщество, политические партии и общественные организации, средства массовой информации, сферу культуры и искусства, бизнес. Опрос экспертов проводился в Ростовской, Курганской, Ленинградской, Рязанской, Свердловской, Смоленской, Ульяновской, Челябинской, Ярославской обл., в Краснодарском, 
Ставропольском, Алтайском, Камчатском, Пермском, Приморском краях, в республиках Башкортостан, Карачаево-Черкесия, Карелия, Коми, Крым, Северная Осетия - Алания, Татарстан, Чувашия. По итогам опроса был издан сборник информационно-аналитических материалов [Рудой и др. 2021].

Анализируя экспертное мнение по ряду задаваемых вопросов и сравнивая оценки демографической ситуации в разных регионах страны, можно сделать вывод, что демографическую ситуацию в стране в настоящее время большинство экспертов определяют как «скорее кризисную». Основными причинами отрицательного естественного прироста в России эксперты считают социально-экономические трудности, политическую нестабильность, затрудненную работу социальных лифтов, девальвацию семейных ценностей.

В качестве наиболее эффективных мер, направленных на решение задач демографического развития России, эксперты большинства регионов на 1-е место поставили «развитие национальных проектов и иных мер, повышающих материальное обеспечение семей» и на 2-е - «воспитание семейных ценностей и соответствующую государственную информационную политику» как устраняющие те причины демографического кризиса в России, которые они посчитали основными и о которых мы говорили выше.

\section{Список литературы}

Рудой В.В., Воронцов С.А., Понеделков А.В., Ляхов В.П., Васьков М.А., Яланский А.П. 2021. Демографическое развитие России: проблемы и пути решения: информационно-аналитические материалы всероссийской научно-практической конференции с международным участием. 26 апреля 2021 г. Ростов н/Д.: Изд-во ЮРИУ РАНХиГС. 320 с.

RYBAKOVSKY Leonid Leonidovich, Dr.Sci. (Econ.), Professor, Chief Researcher at the Institute of Demographic Research - Branch of the Federal Center of Theoretical and Applied Sociology, Russian Academy of Sciences (bld. 1, 6 Fotievoj St, Moscow, Russia, 119333)

KUZINA Svetlana Ivanovna, Dr.Sci. (Pol. Sci.), Professor of the Chair of Political Science and Ethnopolitics, SouthRussian Institute of Management - Branch of Russian Presidential Academy of National Economy and Public Administration (70 Pushkinskaja St, Rostov-on-Don, Russia, 344002)

PONEDELKOV Aleksandr Vasil'evich, Dr.Sci. (Pol.Sci.), Professor; Head of the Chair of Political Science and Ethnopolitics, Head of the Laboratory for Problems of Promotion Efficiency of State and Municipal Administration, South-Russian Institute of Management - Branch of Russian Presidential Academy of National Economy and Public Administration (70/54 Pushkinskaya St, Rostov-on-Don, Russia, 344002; ponedelkov@uriu.ranepa.ru); Honored Scientist of the Russian Federation

\section{EXPERT COMMUNITY OPINION ABOUT THE DEMOGRAPHIC SITUATION IN MODERN RUSSIA}

Abstract. The article considers the demographic situation in modern Russia. The analysis of the results of an expert survey conducted in the regions of Russia allowed authors to identify the main causes of depopulation and then to outline the directions of state policy to overcome the demographic crisis.

Keywords: demographic crisis, natural growth, depopulation, population, state policy, regions of Russia, demographic development 